\title{
Indonesian Dental Students' Attitudes, Knowledge, Preparation, and Willingness to Treat HIV/AIDS Patients
}

\author{
Yuniardini Septorini Wimardhani ${ }^{1} \quad$ Yuli Fatzia Ossa ${ }^{2} \quad$ Indriasti Indah Wardhany ${ }^{1}$ Diah Ayu Maharani ${ }^{3}$ \\ Cliff Lee 4
}

${ }^{1}$ Department of Oral Medicine, Faculty of Dentistry, Universitas Indonesia, Jakarta, Indonesia

2 Oral Medicine Residency Program, Faculty of Dentistry, Universitas Indonesia, Jakarta, Indonesia

${ }^{3}$ Department of Preventive and Public Health Dentistry, Faculty of Dentistry, Universitas Indonesia, Jakarta, Indonesia

${ }^{4}$ Department of Oral Medicine, Immunity and Infection, Harvard School of Dental Medicine, Boston, Massachusetts, United States

\begin{abstract}
Address for correspondence Yuniardini Septorini Wimardhani, DDS, MSc, PhD, Department of Oral Medicine, Faculty of Dentistry Universitas Indonesia, Salemba Raya 4 Jakarta, Indonesia (e-mail: yuniardini@ui.ac.id).
\end{abstract}

Eur J Dent 2022;16:867-874.

\begin{abstract}
Keywords

- HIV

- dental care

- attitude

- willingness to treat

- dental education

- Indonesia

Objective To assess the Indonesian dental students' knowledge of HIV/AIDS in terms of transmission and oral manifestation, the attitudes toward people living with HIV/AIDS (PLWHA), the preparedness in infection control, and willingness to treat PLWHA, and assess the factors for willingness to treat PLWHA.

Materials and Methods A modified version of a questionnaire used to assess dental students' knowledge, attitude, preparedness, and willingness to treat PLWHA in China was used. The questionnaire was cross-culturally adapted into Indonesian and had been pre-tested for face validity and test and retest reliability. The dental students from 32 dental schools in Indonesia were invited to participate in the study.

Results A total of 1,280 dental students from 23 dental schools participated in the study. This study found that only $63 \%$ of students scored higher than $70 \%$ for knowledge of HIV/AIDS, and the mean score for knowledge was 15.02 (2.4). Higher than $80 \%$ of students had a positive professional attitude toward PWLHA; however, $80 \%$ of students worried about possible disease transmission in the dental office by PLWHA and $70 \%$ of students overestimated the occupational risk when treating PLWHA. The dental students had good preparedness for infection control with a mean score for preparedness of 3.19 (0.4). The mean score for willingness was $2.5(0.9)$. Willingness to treat significantly differed by the type of universities, gender, age, and clinical experience. This study showed that knowledge about HIV/AIDS correlated with the willingness to treat PLWHA among dental students. Conclusion Dental students who have good knowledge about HIV infection tend to have a good willingness to treat PLWHA. The knowledge would in turn affect their attitude, preparedness, and willingness to provide care for PLWHA with confidence and comfort. This study suggests that the improvement of dental training may play an important role in changing students' perception of willingness to treat PLWHA.
\end{abstract}

published online January 6, 2022
DOI https://doi.org/

10.1055/s-0041-1740350. ISSN 1305-7456.
(C) 2022. The Author(s).

This is an open access article published by Thieme under the terms of the Creative Commons Attribution License, permitting unrestricted use, distribution, and reproduction so long as the original work is properly cited. (https://creativecommons.org/licenses/by/4.0/)

Thieme Medical and Scientific Publishers Pvt. Ltd., A-12, 2nd Floor, Sector 2, Noida-201301 UP, India 


\section{Introduction}

In Indonesia, as of December 2020, an estimated 543.100 people was living with HIV/AIDS (PLWHA) which is $~ 0.2 \%$ of the total population of Indonesia. This number has continued to grow since first reported in $1987 .{ }^{1}$ There are some oral manifestations associated with HIV or with its treatment that are related to the progress of HIV infection. ${ }^{2}$ These oral manifestations may cause pain and dysfunction in the mouth. When the condition is left untreated, it may influence the systemic condition and quality of life for PLWHA. ${ }^{3}$ However, many studies have shown that PLWHA faces barriers when seeking care. Stigma from healthcare workers is one of the identified barriers for PLWHA to having dental care they need. ${ }^{4}$ Some factors related to barriers from dental providers include fear of HIV transmission, disease-related, and social stigma, and the limited knowledge about the oral manifestation of HIV. ${ }^{5,6}$ Data showing the unmet dental care needs of PLWHA in Indonesia have not been identified; however, in the USA, the proportion of PLWHA with unmet dental care reached up to $65 \%$. ${ }^{7,8}$

Physicians and dentists are expected to properly treat PLHWA as stated by the World Health Organization (WHO) over 30 years ago on the first World's AIDS day in 1988. However, even now, negative attitudes and refusal to treat PLWHA are still documented in many countries worldwide. ${ }^{9}$ In Indonesia, there has not been a national survey to explore dentists' knowledge, attitude, and willingness to treat PLWHA; however, previous studies in several cities and institutions in Indonesia on the topic have been done. ${ }^{10-12}$ Overall, the results indicated the need to improve the willingness to treat PLWHA although the results were contradictory in a study of a single institutional study. ${ }^{12}$ An increase in the number of PLWHA seeking dental care is expected as the population continues to grow. To be able to provide optimal care with confidence and comfort, dentists should be equipped with proper knowledge about HIV/AIDS, a positive attitude, and adequate infection control. Dentists should have continuing education related to the topic and dental students as future dentists should have education and training that could cover those aspects. ${ }^{13}$

The eighth World Workshop on Oral Health and Disease in AIDS (WW8 AIDS) held in Bali 2019 issued a declaration for ending the stigma against HIV/AIDS. ${ }^{14}$ The contents of the declaration included the role of the dentist recognized as an integral part of the healthcare team committed to achieving the aims of the United Nations Programme on HIV/AIDS (UNAIDS). The HIV education of dental students and dental healthcare workers should be an essential element of the dental curriculum to ensure the profession has the appropriate knowledge and attitudes to manage PLWHA, and public health programs make certain that the general public is aware of the role of dental healthcare workers and normalizing attitudes to PLWHA. ${ }^{14}$ Previous studies in several countries such as China, Malaysia, India, the UK, Egypt, and Africa have shown that there was still a need for improvement in shaping dental students' attitudes to prepare them to treat PLWHA by increasing their knowl- edge. ${ }^{9,15-20}$ Currently, studies that explore the students' knowledge, attitude, preparedness, and willingness to treat PLWHA are still limited in Indonesia; therefore, a comparison of results to those previous studies could not be performed. As knowledge, attitude, and preparedness in infection control are some factors that were indicated to influence the willingness to treat PLWHA, this study aimed to assess the Indonesian dental students' knowledge of HIV/AIDS in terms of transmission and oral manifestation, the attitudes toward PLWHA, the preparedness in infection control, and the willingness to treat PLWHA. In addition, the relationship between these factors and willingness to treat PLWHA was also explored.

\section{Materials and Methods}

\section{Study Design}

This was a cross-sectional questionnaire-based study to assess the knowledge, attitude, preparedness, and willingness of dental students across Indonesia to treat patients with HIV/AIDS. This study was approved by the Research Ethics Committee of the Faculty of Dentistry Universitas Indonesia (No. 67/Ethical Approval/FKGUI/VIII/2019). The questions used were modified from a questionnaire developed and reported in a previous study. ${ }^{16}$

\section{Questionnaire}

The questionnaire was cross-culturally adapted using the guidelines for cross-cultural adaptation. All the crossadaptation process was performed to finally use the Indonesian version of the questionnaire. ${ }^{21,22}$ The questionnaire consisted of five sections, which were demographic data, knowledge (21 questions, scale $0-1$ ), attitude (14 questions, scale1-4), preparedness (16 questions, scale 1-4), and willingness (1 question, scale 1-4). In the knowledge section, students were asked to provide a "true" or "false" or "do not know." Each right answer was scored 1, and false or do not know the answer was scored 0 . For attitude, preparedness, and willingness, a 4-point Likert scale was used. The data analysis was based on the total score value of the answers for knowledge, attitude, preparedness, and willingness analyzed based on the mean Likert score.

\section{Study Participants}

The sampling frame consisted of all students from 32 dental schools in Indonesia who were at the clinical stage of the dentistry program (years 4 and 5). Permission from all Deans of the dental schools was granted before the distribution of the questionnaire. The questions were arranged in an electronic form (Google Form) and distributed to the students through each dental school coordinator. After the permission was granted from each school, the questionnaire was distributed to the students and opened for 2 weeks. The students provided written informed consent to participate in the study. Any participant who did not complete the questionnaire was excluded from the study. Data were collected during October-November 2019. 


\section{Data Analysis}

The statistical analyses were performed using SPSS software version 23.0. Descriptive statistics were calculated, and bivariate analyses were performed. The relationships between the levels of knowledge, attitude, preparedness, and willingness to treat PLWHA with sociodemographic characteristics were analyzed using Mann-Whitney and KruskalWallis tests. Correlation of knowledge, attitude, and preparedness with the willingness to treat PLWHA was done using Spearman's correlation analysis. A significance level of 0.05 was used for all analyses.

\section{Results}

The demographic data of respondents are shown in $\boldsymbol{- T a b l e} \mathbf{1}$. There were 23 (71.9\%) dental schools that agreed to participate in the study. The total number of respondents was 1,280 with the number of female students five times higher than male students. The number of students who participated from public universities was almost 10\% higher than those from private ones. Most of the students were in their second year of the clinical year (49.5\%).

\section{Knowledge about HIV}

Overall, $63 \%$ of students scored $70 \%$ or higher. Almost all students correctly answered blood as a mode of transmission; however, only $11 \%$ of students could recognize that HIV could be potentially transmissible through aerosols ( - Table 2). Furthermore, $65 \%$ of students thought that sputum could transmit HIV, and $50.9 \%$ of students incorrectly believed that saliva was a way of HIV transmission. Around $25 \%$ of students thought that HIV is transmissible through insect bites and tears and only $20 \%$ of students were aware of the number of PLWHA in their region. In terms of knowledge of oral manifestations, the

Table 1 Characteristics of students who participated to the study

\begin{tabular}{|c|c|}
\hline Characteristics & $n(\%)$ \\
\hline \multicolumn{2}{|c|}{ Type of university } \\
\hline Public & $701(54.8)$ \\
\hline Private & $579(45.2)$ \\
\hline \multicolumn{2}{|l|}{ Sex } \\
\hline Male & $212(16.5)$ \\
\hline Female & $1068(83.3)$ \\
\hline \multicolumn{2}{|l|}{ Age } \\
\hline$<25$ & $1015(79.3)$ \\
\hline$\geq 25$ & $265(20.7)$ \\
\hline \multicolumn{2}{|c|}{ Year of clinical experience } \\
\hline 1 year & $370(28.9)$ \\
\hline 2 years & $634(49.5)$ \\
\hline$>2$ years & $276(21.6)$ \\
\hline
\end{tabular}

lowest percentage of correct answers from students was about xerostomia and aphthous ulcers. Many students mistakenly believe that oral lichen planus and peripheral ossifying fibroma were oral manifestations of HIV. Students from public universities had a higher score of knowledge than those from private universities and the difference was statistically significant $(p<0.05)(-$ Table 5).

\section{Attitude Toward PLWHA}

- Table 3 shows the Indonesian dental students' attitudes toward PLWHA. This study used 14 statements to assess students' attitudes toward PLWHA. The statements were divided into three different domains. The domains were professionalism, opinion and feelings, and personal assurance. Higher than $80 \%$ of students had a positive professional attitude toward PLWHA. In the opinions and feeling domain, the majority felt that their professional education had provided enough information to work safely with PLWHA and they agreed that they should not refuse to treat PLWHA and did not have negative feelings toward PLWHA. However, $\sim 80 \%$ of the students still had worries that PLWHA were responsible to transmit the disease and would refer the patient to be treated elsewhere. In the personal assurance domain, only almost $50 \%$ of students were sure that they knew the post-exposure procedures/protocols, and $70 \%$ of students were worried about their safety when treating PLWHA. Overall, the results showed that dental students tended to have a positive attitude toward PLWHA with a mean score of $3.04(0.3)$. None of the students' characteristics were associated with the attitude toward PLWHA ( - Table 5 ).

\section{Preparedness of Infection Control}

- Table 4 shows the Indonesian dental students' preparedness regarding infection control when treated PLWHA. Although they agreed that all patients should be considered potentially infectious, the majority of the students would change/enhance their practice of infection control when treating known PLWHA. There was still a low percentage of dental students who were not prepared to practice proper infection control. For example, there were $3.0 \%$ of dental students who rarely or only sometimes routinely wore gloves when doing procedures. The results of this study showed that overall, dental students had good preparedness for infection control with a mean score for preparedness of $3.19(0.4)$. Students who were female and from the public universities had a higher preparedness score than those who were male and from the private universities $(p<0.05)$ ( - Table 5 ).

\section{Willingness to Treat PLWHA}

Dental students' willingness to treat PLWHA had the lowest score compared with other aspects that were explored in this study. The dental students were asked about their willingness to treat PLWHA. Only $14.5 \%$ of dental students were willing to treat without any doubt. The mean score for willingness was 2.5 (0.9). - Table 5 describes the distribution of the willingness mean score by students' characteristics. 
Table 2 Indonesian dental students' knowledge of HIV/AIDS

\begin{tabular}{|c|c|c|c|c|c|}
\hline \multicolumn{2}{|c|}{ Knowledge } & \multicolumn{4}{|c|}{ Responses $(N=1280)$} \\
\hline & & \multicolumn{2}{|c|}{ Correct } & \multicolumn{2}{|c|}{ Incorrect } \\
\hline & & $n$ & $\%$ & $n$ & $\%$ \\
\hline \multicolumn{6}{|c|}{ Mode of HIV transmission } \\
\hline \multirow[t]{5}{*}{ Yes } & Aerosol (contaminated by blood) & 142 & 11.1 & 1138 & 88.9 \\
\hline & Blood & 1273 & 99.5 & 7 & 0.5 \\
\hline & Breast milk & 1080 & 84.4 & 200 & 15.6 \\
\hline & Semen & 1139 & 89.0 & 141 & 11.0 \\
\hline & Vaginal secretion & 1164 & 90.9 & 48 & 3.8 \\
\hline \multirow[t]{4}{*}{ No } & Insect bites & 932 & 72.8 & 348 & 27.2 \\
\hline & Sputum & 438 & 34.2 & 842 & 65.8 \\
\hline & Saliva & 628 & 49.1 & 652 & 50.9 \\
\hline & Tears & 961 & 75.1 & 319 & 24.9 \\
\hline \multicolumn{6}{|c|}{ Oral manifestations related to HIV/AIDS } \\
\hline \multirow[t]{7}{*}{ Yes } & Kaposi's sarcoma & 742 & 58.0 & 538 & 42.0 \\
\hline & Oral candidiasis & 1177 & 92.0 & 103 & 8.0 \\
\hline & Acute necrotizing ulcerative gingivitis & 876 & 68.4 & 404 & 31.6 \\
\hline & Hairy leukoplakia & 1022 & 79.8 & 258 & 20.2 \\
\hline & Herpes simplex lesion & 779 & 60.9 & 501 & 39.1 \\
\hline & Xerostomia & 627 & 49.0 & 653 & 51.0 \\
\hline & Aphthous ulcer & 648 & 50.6 & 632 & 49.4 \\
\hline \multirow[t]{3}{*}{ No } & Fordyce granules & 900 & 70.3 & 380 & 29.7 \\
\hline & Peripheral ossifying fibroma & 593 & 46.3 & 687 & 53.7 \\
\hline & Lichen planus & 440 & 34.4 & 840 & 65.6 \\
\hline \multicolumn{2}{|c|}{ Blood has the highest virus concentration } & 1124 & 87.8 & 156 & 12.2 \\
\hline \multicolumn{2}{|c|}{ Knowledge about number of PLWHA in the region } & 269 & 21.0 & 1011 & 79.0 \\
\hline
\end{tabular}

The score was significantly differed by the type of university, gender, age, and clinical experience.

\section{Correlation of Knowledge, Attitude, and Preparedness with Willingness to Treat PLWHA}

This study did not find any correlation between attitude and preparedness of infection control with students' willingness to treat PLWHA $(r<0.1)$. Although the correlation was very low between knowledge of HIV/AIDS with the willingness to treat, the correlation was statistically significant $(p<0.05)$. The knowledge of HIV/AIDS and attitude toward PLWHA also had a statistically significant correlation with the preparedness for infection control $(p<0.05)$. - Table 6 describes the $r$ value of Spearman's correlation analysis of variables.

\section{Discussion}

This study investigated several aspects related to knowledge, attitude, preparedness, and willingness of Indonesian dental students toward PLWHA. This study aimed to explore the relation of dental students' knowledge, attitude, and preparedness with the willingness to treat PLWHA. This study was performed as a response to the trend of HIV infection worldwide and in Indonesia and attributed to the recent publication related to HIV education that suggested that there is a need to evaluate the course format and content to appropriately provide education and training to dental students. ${ }^{23}$ Students from more than half of the 32 dental schools in Indonesia participated in this study, with a representative composition in relation to age, clinical experience, and type of university. However, females seemed to be overrepresented and response bias may not be ruled out. We adapted the previously used questionnaire to assess the same aspects in Indonesian settings. This study used a questionnaire that was applied for research in China. ${ }^{16}$ The original questionnaire was in English and Chinese that was cross-culturally adapted into Indonesian using the previously published method. ${ }^{21}$

The knowledge about HIV/AIDS correlated with willingness to treat PLWHA among Indonesian dental students. Many studies have indicated the need for more interactive activities that stimulate experiential learning for dental students on HIV/AIDS topics that may influence their knowledge gain, empathy, and reduce stigma; therefore, attributed 
Table 3 Indonesian dental students' attitude toward PLWHA

\begin{tabular}{|c|c|c|c|c|}
\hline \multirow[t]{2}{*}{ Domain } & $\begin{array}{l}\text { Strongly } \\
\text { disagree }\end{array}$ & Disagree & Agree & $\begin{array}{l}\text { Strongly } \\
\text { agree }\end{array}$ \\
\hline & $1 n(\%)$ & $2 n(\%)$ & $3 n(\%)$ & $4 n(\%)$ \\
\hline \multicolumn{5}{|l|}{ 1. Professionalism } \\
\hline $\begin{array}{l}\text { You need more training/learning about HIV oral manifestations and how } \\
\text { to treat PLWHA in the faculty of dentistry }\end{array}$ & $17(1.3)$ & $31(2.4)$ & $243(19.0)$ & $989(77.3)$ \\
\hline HIV status must be disclosed and become part of the patient's archive & $47(3.7)$ & $86(6.7)$ & $328(25.6)$ & $819(64.0)$ \\
\hline You have ethical responsibilities to provide dental care to PLWHA & $24(1.9)$ & $83(6.5)$ & $430(33.6)$ & $743(58.0)$ \\
\hline All patients must be considered potentially infectious & $58(4.5)$ & $85(6.6)$ & $339(25.5)$ & $798(62.3)$ \\
\hline You must behave toward PLWHA as well as non-HIV patients & $78(6.1)$ & $134(10.5)$ & $421(32.9)$ & $647(50.5)$ \\
\hline \multicolumn{5}{|l|}{ 2. Opinion and feelings } \\
\hline If you have an option, you would prefer to refer HIV patient to anywhere else & $80(6.3)$ & $169(13.2)$ & $528(41.3)$ & $520(40.6)$ \\
\hline Professional health workers should not refuse to treat PLWHA & $174(13.6)$ & $294(23.0)$ & $446(34.8)$ & $366(28.6)$ \\
\hline You do not have negative feelings toward people living with HIV & $111(8.7)$ & $307(24.0)$ & $501(39.1)$ & $361(29.2)$ \\
\hline $\begin{array}{l}\text { Your professional education has provided enough information to work } \\
\text { safely with PLWHA }\end{array}$ & $26(2.0)$ & 101 (7.9) & $425(35.3)$ & $701(54.8)$ \\
\hline You think your patients will be worried of they know you have treated PLWHA & $63(4.9)$ & $169(13.2)$ & $528(41.3)$ & $520(40.6)$ \\
\hline PLWHA are responsible for transmitting the disease & $98(7.7)$ & $261(20.4)$ & $420(32.8)$ & $501(39.1)$ \\
\hline \multicolumn{5}{|l|}{ 3. Personal assurance } \\
\hline You know the HIV post-exposure procedures/protocols & $235(18.4)$ & $453(35.4)$ & $432(33.0)$ & $169(13.2)$ \\
\hline $\begin{array}{l}\text { You are worried (or may worry) about your own safety when treating } \\
\text { PLWHA }\end{array}$ & $77(6.0)$ & $295(23.0)$ & $513(40.1)$ & $395(30.9)$ \\
\hline $\begin{array}{l}\text { Your view of people living with HIV does not change the way you treat } \\
\text { PLWHA }\end{array}$ & $121(9.5)$ & $261(20.4)$ & $544(42.5)$ & $354(27.7)$ \\
\hline
\end{tabular}

Table 4 Distribution of dental students preparations regarding infection control when treated for PLWHA

\begin{tabular}{|c|c|c|c|c|}
\hline \multirow[t]{2}{*}{ Domain } & Rarely & Sometimes & Usually & Always \\
\hline & $1 n(\%)$ & $2 n(\%)$ & $3 n(\%)$ & $4 n(\%)$ \\
\hline \multicolumn{5}{|l|}{ Infection control practice } \\
\hline Wearing gloves during the procedure & $12(0.9)$ & $27(2.1)$ & $394(30.8)$ & $847(66.2)$ \\
\hline Changing glove after patient's treatment & $16(1.3)$ & $26(2.0)$ & $377(29.5)$ & $861(67.3)$ \\
\hline Sterilize the instrument before use & $15(1.2)$ & $30(2.3)$ & $387(30.2)$ & $848(66.3)$ \\
\hline Changing instruments between patients & $29(2.3)$ & $44(3.4)$ & $383(29.9)$ & $824(64.4)$ \\
\hline Wearing personal protective equipment (excluding gloves) & $40(3.1)$ & $109(8.5)$ & $441(34.5)$ & $690(53.9)$ \\
\hline Retrieve/update the patient's medical history & $39(3.0)$ & $132(10.3)$ & $491(38.4)$ & $618(48.3)$ \\
\hline Using disinfectants and /or replacing protectors on the unit & $41(3.2)$ & $147(11.5)$ & $481(37.6)$ & $611(47.7)$ \\
\hline Sterilizing personal protective equipment & $55(4.3)$ & $187(14.6)$ & $488(38.1)$ & $550(43.0)$ \\
\hline \multicolumn{5}{|l|}{ Appropriate handling of patient care } \\
\hline Change treatment to examine specific HIV manifestations & $130(10.2)$ & $196(15.3)$ & $522(40.8)$ & $432(33.8)$ \\
\hline Extra or different sterilization/disinfection & $42(3.3)$ & $66(5.2)$ & $530(41.4)$ & $642(50.2)$ \\
\hline Refer to a public health clinic & $149(11.6)$ & $245(19.1)$ & $425(35.3)$ & $434(33.9)$ \\
\hline Change treatment to shorten procedures & $378(29.5)$ & $347(27.1)$ & $335(26.2)$ & $220(17.2)$ \\
\hline Treat in different room/location & $278(21.7)$ & $301(23.5)$ & $372(29.1)$ & $329(25.7)$ \\
\hline Wearing personal protective equipment & $34(2.7)$ & $68(5.3)$ & $529(41.3)$ & $649(50.7)$ \\
\hline Inform your staff about the patient's health status & $122(9.5)$ & $127(9.9)$ & $452(35.3)$ & $579(45.2)$ \\
\hline Request the patients to use protective goggles & $395(30.9)$ & $427(33.4)$ & $261(20.4)$ & $197(15.4)$ \\
\hline
\end{tabular}


Table 5 Distribution of students based on their knowledge, attitude, preparedness, and willingness related to HIV/AIDS

\begin{tabular}{|c|c|c|c|c|c|c|c|c|}
\hline \multirow[t]{2}{*}{ Characteristics } & \multicolumn{2}{|c|}{ Knowledge of HIV } & \multicolumn{2}{|c|}{$\begin{array}{l}\text { Attitude toward } \\
\text { PLWHA }\end{array}$} & \multicolumn{2}{|c|}{$\begin{array}{l}\text { Preparedness in infec- } \\
\text { tion control }\end{array}$} & \multicolumn{2}{|c|}{$\begin{array}{l}\text { Willingness to treat } \\
\text { PLWHA }\end{array}$} \\
\hline & Mean (SD) & $p$-value & Mean (SD) & $P$-value & Mean (SD) & $P$-value & Mean (SD) & $P$-value \\
\hline \multicolumn{9}{|c|}{ Type of university } \\
\hline Public & $15.52(2.4)$ & $0.001^{*}$ & $3.04(0.3)$ & 0.33 & $3.19(0.4)$ & $0.009^{*}$ & $2.59(0.9)$ & $0.037^{*}$ \\
\hline Private & $14.52(2.5)$ & & $3.05(0.3)$ & & $3.12(0.4)$ & & $2.49(0.9)$ & \\
\hline \multicolumn{9}{|l|}{ Sex } \\
\hline Male & $14.75(2.5)$ & 0.12 & $3.03(0.3)$ & 0.73 & $3.07(0.5)$ & $0.01^{*}$ & $2.38(0.8)$ & $0.08^{*}$ \\
\hline Female & $15.13(2.5)$ & & $3.05(0.3)$ & & $3.17(0.4)$ & & $2.57(0.9)$ & \\
\hline \multicolumn{9}{|l|}{ Age } \\
\hline$<25$ & $15.0(2.5)$ & 0.25 & $3.04(0.3)$ & 0.32 & $3.17(0.4)$ & 0.11 & $2.57(0.9)$ & $0.01^{*}$ \\
\hline$\geq 25$ & $15.2(2.5)$ & & $3.06(0.4)$ & & $3.11(0.5)$ & & $2.40(0.9)$ & \\
\hline \multicolumn{9}{|c|}{ Year of clinical experience } \\
\hline 1 year & $14.87(2.6)$ & 0.20 & $3.02(0.3)$ & 0.44 & $3.18(0.4)$ & 0.34 & $2.51(0.9)$ & $0.03^{* *}$ \\
\hline 2 years & $15.19(2.3)$ & & $3.05(0.3)$ & & $3.17(0.4)$ & & $2.60(0.9)$ & \\
\hline$>2$ years & $15.06(2.6)$ & & $3.01(0.4)$ & & $3.10(0.5)$ & & $2.43(0.9)$ & \\
\hline
\end{tabular}

${ }^{*} p<0.05$ Mann-Whitney test*; and Kruskal-Wallis test**.

Table 6 Correlations (Spearman's correlations) between knowledge, attitude, preparedness, and willingness related to HIV/AIDS among dental students in Indonesia

\begin{tabular}{|l|l|l|l|l|}
\hline & Knowledge & Attitude & Preparedness & Willingness \\
\hline Knowledge & 1 & & & \\
\hline Attitude & 0.01 & 1 & & \\
\hline Preparedness & $0.08^{*}$ & $0.20^{*}$ & 1 & \\
\hline Willingness & $0.06^{*}$ & 0.01 & 0.01 & 1 \\
\hline
\end{tabular}

${ }^{*}$ Correlations were significant at $p<0.05$.

to the increase of willingness to treat PLWHA. ${ }^{23}$ Fear and stigma related to PLWHA is a problem faced by many countries and not only confined to countries with a specific culture or religion. ${ }^{9}$ Studies have shown that the unwillingness to treat PLWHA resulted from preconceived assumptions and misconceptions about the condition. ${ }^{24,25}$ Other factors also include the fear of being infected with HIV, personal values, religious and socio-cultural values, and norms. ${ }^{26,27}$ A recent study in Indonesia showed that stigma among health care providers toward PLWHA is still high. ${ }^{26}$ Based on the results of this study, improvement of the dental curriculum on HIV/AIDS may significantly improve attitudes toward and willingness to treat PLWHA. ${ }^{28}$ Several studies have argued that the methods of learning related to HIV/AIDS topics should be modified during dental training. Besides emphasizing teaching, the knowledge about HIV/AIDS transmission, universal precaution, teaching appropriate technical skills, and interpersonal skills need to deliver effective dental care to PLWHA is also important. As also been proposed by other studies, opportunities to have an interaction with PLWHA would be essential to ensure dental stu- dents to be professional and competent in managing PLWHA in Indonesia. ${ }^{16,23}$

The Indonesian dental students tended to have a positive attitude toward PLWHA, and none of the students' characteristics were associated with the attitude toward PLWHA. The dental students' attitude had a correlation with their preparedness related to infection control. Although in general, dental students had a positive attitude toward PLWHA, the overwhelming majority would prefer to refer PLWHA elsewhere if given the choice. These results were similar to previous studies in China, Kuwait, Brazil, and Canada. ${ }^{16,29-31}$ The students overestimated disease transmission by PLWHA in dental practice, which made the negative attitude of thinking that they should be treated somewhere else. This worry may be attributed to the misperception of the risk of HIV transmission in dental practice as a result of occupational risks. A previous study showed that oral health care workers did not know that saliva contains anti-HIV activity and erroneously believed that saliva without blood contamination could transmit HIV, and thought that dental professionals have a high risk of being infected by HIV compared with other health care providers. ${ }^{32}$ The students were still worried about their safety when treating PLWHA despite practicing universal precaution, which can translate to negative attitudes toward PLWHA. ${ }^{33}$ Dental training includes dental professionalism that emphasizes equal and non-judgmental service to all; however, many studies showed that many biases that influence professionalism are experienced by PLWHA. ${ }^{4,34}$

The majority of students practiced proper infection control when treating patients with standard/universal precaution. ${ }^{35}$ The students also agreed that they should treat all patients to be potentially infectious. This study showed that female students and students from public universities 
significantly had a higher score of preparedness for infection control. Although a previous study believed that the gender difference did not influence the access to oral care to PLWHA, the possible explanation for this results may be because males were actually more concerned about the cost with regard to spending for infection control compared with females. ${ }^{30}$ This study showed that only a small proportion of dental students knew the range of the number of PLWHA in their province, so we could not see the relation whether this could cause more compliance with infection control, as seen in the previous study. ${ }^{16}$ Dental students in this study answered that they would be more cautious when they know they are treating PLWHA and make extra protection in terms of the PPE and patient wearing goggles, which is in contradiction to universal precaution. The infection control measures in the healthcare setting for universal precaution is for bloodborne pathogens such as HIV transmission, and not the same standard for respiratory transmission such as with the SARS-CoV-2. ${ }^{36,37}$ The data collection for this study was performed before the pandemic started.

Only $50 \%$ of dental students had a positive answer that they will treat PLWHA without any doubt. This study showed that dental students' willingness to treat PLWHA without any doubt significantly differed by the type of university, gender, age, and year of clinical experience. The results were similar to other previous studies that showed this pattern. ${ }^{10,30,38}$ The students have had 1 to 2 years' clinical activities in the dental schools at the time the study was conducted. This study showed that the long experience in clinical activities had improved scores in the knowledge about HIV/AIDS as well as the willingness to treat PLWHA. In our study, the majority of respondents already knew correctly the mode of HIV/AIDS transmission, which is in line with the research on the transmission of HIV disease that was conducted in Israel. ${ }^{38}$ However, in this study, there were still some dental students who did not have correct answers about the transmission mode of HIV. This lack of knowledge may reflect that there is still room for improvement to increase the students' knowledge. Overall, this study showed that students from public dental schools had a higher score compared with the private dental school's ones in terms of knowledge, preparedness, and willingness to treat PLWHA. The results of this current study are completely comparable with those of a previous study in China. ${ }^{16}$ These results implicate a possible room for improvement related to the increase in the knowledge in dental students, implemented in the same standard of learning method related to the subject throughout dental schools in the country. The previous study in India has indicated that training and education in an advanced curriculum provided to dental students were sufficient to handle PLWHA. ${ }^{13}$

\section{Conclusion}

Several aspects related to knowledge, attitude, preparedness, and willingness of Indonesian dental students toward PLWHA were explored. This study demonstrated the need to improve teaching methods to increase the knowledge of dental students, implemented in the same standard of learning method related to the subject throughout dental schools in the country. The methods that would stimulate experiential learning for dental students on HIV/AIDS topics that may influence their knowledge gain, empathy, and reducing stigma; therefore, attributed to the increase in the willingness to treat PLWHA. The role of dental schools in Indonesia should be to provide dental training, specifically implementing modifications in the methods of learning for HIV/AIDS, which would be essential to increase oral care access for PLWHA in the future.

Funding

This study was supported by the Universitas Indonesia Research Award (grant no. NKB-1604/UN2.RST/ HKP.05.00/ 2020).

Conflict of Interest

None declared.

Acknowledgments

We would like to express our thank to all the Program Coordinators from all the Dental Schools whose students had participated in this study.

\section{References}

1 Indonesian HIV/AIDS information system. [Internet] Accessed July 1 , 2021 at: https://siha.kemkes.go.id/portal/files_upload/Laporan_TW_IV_2020.pdf

2 Patton LL. Oral lesions associated with human immunodeficiency virus disease. Dent Clin North Am 2013;57(04):673-698

3 Patton LL, Phelan JA, Ramos-Gomez FJ, Nittayananta W, Shiboski $\mathrm{CH}$, Mbuguye TL. Prevalence and classification of HIV-associated oral lesions. Oral Dis 2002;8(Suppl 2):98-109

4 Brondani MA, Phillips JC, Kerston RP, Moniri NR. Stigma around HIV in dental care: Patients' experiences. J Can Dent Assoc 2016; $82: \mathrm{g} 1$

5 Brown L, Macintyre K, Trujillo L. Interventions to reduce HIV/AIDS stigma: what have we learned? AIDS Educ Prev 2003;15(01): 49-69

6 Wagner AC, Hart TA, McShane KE, Margolese S, Girard TA. Health care provider attitudes and beliefs about people living with HIV: Initial validation of the Health Care Provider HIV/AIDS Stigma Scale (HPASS). AIDS Behav 2014;18(12):2397-2408

7 Jeanty Y, Cardenas G, Fox JE, et al. Correlates of unmet dental care need among HIV-positive people since being diagnosed with HIV. Public Health Rep 2012;127(Suppl 2):17-24

8 Fox JE, Tobias CR, Bachman SS, Reznik DA, Rajabiun S, Verdecias N. Increasing access to oral health care for people living with HIV/AIDS in the U.S.: baseline evaluation results of the innovations in Oral Health Care Initiative. Public Health Rep 2012;127 (Suppl 2):5-16

9 Abou El Fadl RK, Abdelmoety A, Farahat Z, Hussein MA. Assessing the levels of HIV-related knowledge and attitudes toward HIVinfected patients among undergraduate dental students: a crosssectional study. HIV AIDS (Auckl) 2019;11:83-92

10 Gunardi I, Salsabila Nurina N, Marcia M, Amtha R. Dentists experience influences knowledge and attitudes toward HIV patients in West Jakarta, Indonesia, and validation of a new questionnaire. Oral Dis 2020;26(Suppl 1):127-132

11 Kadrianto TH, Subita GP, Aliyah S. Willingness of dentists in Jakarta in treating patients with HIV/AIDS. Thesis Universitas Indonesia 2014 
12 Pratiwi R, Akbar FH, Pasiga B, et al. Description of the level of knowledge, preparedness and willingness of the Faculty of Dentistry, Hasanuddin University in caring for people with HIV/AIDS. J Int Dent Med Res 2019;12(02):688-694

13 Vijayalaxmi N, Reddy L, Swapna LA, Reddy S, Ramesh T, Padmareddy M. Are you willing to treat patients with HIV/AIDS? An anonymous survey among staff and students of dental institution. Oral Health Dent Manag 2014;13(03):745-748

14 FDI World Dental Federation. The Bali Declaration on Oral Health in HIV/AIDS. 2019. Published 2019. Accessed December 9, 2019 at: https://www.fdiworlddental.org/bali-declaration-oral-healthhivaids-dentists-can-help-end-epidemic-2030

15 Singh VP, Osman IS, Rahmat NA, Bakar NAA, Razak NFNA, Nettem S. Knowledge and attitude of dental students towards HIV/AIDS patients in Melaka. Malays J Med Sci 2017;24(03): 73-82

16 Lee C, Fan Y, Starr JR, Dogon IL. Dentists' and dental students' attitudes, knowledge, preparedness, and willingness related to treatment of people living with HIV/AIDS in China. J Public Health Dent 2017;77(01):30-38

17 Azodo CC, Ehigiator O, Oboro HO, et al. Nigerian dental students' willingness to treat HIV-positive patients. J Dent Educ 2010;74 (04):446-452

18 Seacat JD, Litt MD, Daniels AS. Dental students treating patients living with HIV/AIDS: the influence of attitudes and HIV knowledge. J Dent Educ 2009;73(04):437-444

19 Fotedar S, Sharma KR, Sogi GM, Fotedar V, Chauhan A. Knowledge and attitudes about HIV/AIDS of students in H.P. Government Dental College and Hospital, Shimla, India. J Dent Educ 2013;77 (09):1218-1224

20 Aggarwal A, Panat SR. Knowledge, attitude, and behavior in managing patients with HIV/AIDS among a group of Indian dental students. J Dent Educ 2013;77(09):1209-1217

21 Beaton DE, Bombardier C, Guillemin F, Ferraz MB. Guidelines for the process of cross-cultural adaptation of self-report measures. Spine 2000;25(24):3186-3191

22 Gjersing L, Caplehorn JR, Clausen T. Cross-cultural adaptation of research instruments: language, setting, time and statistical considerations. BMC Med Res Methodol 2010;10(10):13

23 Ranauta A, Tappuni AR, Coulthard P. HIV teaching: a dental curriculum which fosters knowledge and attitude. Oral Dis 2020;26(Suppl 1):123-126

24 Askarian M, Mirzaei K, Assadian O. Iranians' attitudes about possible human immunodeficiency virus transmission in dental settings. Infect Control Hosp Epidemiol 2007;28(02): $234-237$
25 Madhan B, Gayathri H, Garhnayak L, Naik ES. Dental students' regard for patients from often-stigmatized populations: findings from an Indian dental school. J Dent Educ 2012;76(02):210-217

26 Fauk NK, Ward PR, Hawke K, Mwanri L. HIV stigma and discrimination: perspectives and personal experiences of healthcare providers in Yogyakarta and Belu, Indonesia. Front Med (Lausanne) 2021;8:625787

27 Szaflarski M. Spirituality and religion among HIV-infected individuals. Curr HIV/AIDS Rep 2013;10(04):324-332

28 Arheiam A, El Tantawi M, Al-Ansari A, et al. Arab dentists' refusal to treat HIV positive patients: a survey of recently graduated dentists from three Arab dental schools. Acta Odontol Scand 2017;75(05):355-360

29 Ellepola ANB, Joseph BK, Sundaram DB, Sharma PN. Knowledge and attitudes towards HIV/AIDS amongst Kuwait University dental students. Eur J Dent Educ 2011;15(03):165-171

30 McCarthy GM, MacDonald JK. Gender differences in characteristics, infection control practices, knowledge and attitudes related to HIV among Ontario dentists. Community Dent Oral Epidemiol 1996;24(06):412-415

31 Oliveira ER, Narendran S, Falcão A. Brazilian dental students' knowledge and attitudes towards HIV infection. AIDS Care 2002;14(04):569-576

32 Taiwo O. Dental practice, human immunodeficiency virus transmission and occupational risks: views from a teaching hospital in Nigeria. Ann Med Health Sci Res 2014;4(Suppl 2):S94-S98

33 Varas-Díaz N, Rivera M, Rivera-Segarra E, et al. Beyond negative attitudes: Examining HIV/AIDS stigma behaviors in clinical encounters. AIDS Care 2017;29(11):1437-1441

34 McLean AT, Wheeler EK, Cameron S, Baker D. HIV and dentistry in Australia: clinical and legal issues impacting on dental care. Aust Dent J 2012;57(03):256-270

35 Centers for Disease Control and Prevention [Internet]. Summary of Infection Prevention Practices in Dental Settings. [cited 2021 Sept 6]. Accessed November 4, 2021 at: https://www.cdc. gov/oralhealth/infectioncontrol/summary-infection-prevention-practices/standard-precautions.html

36 Volgenant CMC, Persoon IF, de Ruijter RAG, de Soet JJH. Infection control in dental health care during and after the SARS-CoV-2 outbreak. Oral Dis 2021;27(Suppl 3):674-683

37 Farook FF, Mohamed Nuzaim MN, Taha Ababneh K, Alshammari A, Alkadi L. COVID-19 Pandemic: oral health challenges and recommendations. Eur J Dent 2020;14(S 01):S165-S170

38 Baytner-Zamir R, Lorber M, Hermoni D. Assessment of the knowledge and attitudes regarding HIV/AIDS among pre-clinical medical students in Israel. BMC Res Notes 2014;7:168 